\section{(A) Check for updates}

Cite this: Dalton Trans., 2018, 47, 4341

Received 19th December 2017, Accepted 19th February 2018

DOI: $10.1039 / \mathrm{c} 7 \mathrm{dt} 04790 \mathrm{~h}$

rsc.li/dalton

\title{
Chlorinated cobalt alkyne complexes derived from acetylsalicylic acid as new specific antitumor agents $\dagger$
}

\author{
Victoria Obermoser,,$^{a}$ Daniel Baecker, $\star^{a}$ Carina Schuster, ${ }^{a}$ Valentin Braun, ${ }^{a}$ \\ Brigitte Kircher ${ }^{\mathrm{b}, \mathrm{c}}$ and Ronald Gust (D) *a
}

\begin{abstract}
[(Prop-2-ynyl)-2-acetoxybenzoate]dicobalthexacarbonyl (Co-ASS), an organometallic derivative of the irreversible cyclooxygenase-1/2 (COX-1/2) inhibitor acetylsalicylic acid (ASS), demonstrated high growthinhibitory potential against various tumor cell lines and inhibition of both COX isoenzymes. With the objective of increasing the selectivity for COX-2, we introduced a chlorine substituent in position 3, 4, 5, or 6 of the ASS moiety, respectively. Increased COX-2 selectivity is desirable as this isoenzyme is predominantly related to the development of cancer and abnormal tissue growth. The new compounds were investigated in comprehensive cellular biological assays to identify the impact of the chlorine substitution at the complex on COX-1/2 inhibition, antiproliferative activity, apoptosis, metabolic activity, cell-based COX inhibition, and cellular uptake. Chlorination distinctly reduced the effects at isolated COX-1 (about $25 \%$ inhibition at $10 \mu \mathrm{M}$; Co-ASS: $82.7 \%$ ), while those at COX-2 remained almost unchanged (about $65 \%$ inhibition at $10 \mu \mathrm{M}$; Co-ASS: 78.5\%). In cellular systems, with exception of the 6 - $\mathrm{Cl}$ derivative, all compounds showed notable antitumor activity in COX-1/2 expressing tumor cells $\left(H \mathrm{HT}-29\left(\mathrm{IC}_{50}=1.5-2.7 \mu \mathrm{M}\right)\right.$, MDA-MB-231 $\left.\left(I C_{50}=5.2-8.0 \mu \mathrm{M}\right)\right)$, but were distinctly less active in the COX-1/2-negative MCF-7 breast cancer cell line $\left(I_{50}=15.2-22.9 \mu \mathrm{M}\right)$. All complexes possess high selectivity for tumor cells, because they did not influence the growth of the non-tumorigenic, human bone marrow stromal cell line HS-5. These findings clearly demonstrate that the interference with the COX-1/2 cascade contributes to the mode of anticancer action of the cobalt alkyne complexes.
\end{abstract}

\section{Introduction}

Cyclooxygenases are homodimeric enzymes catalyzing the conversion of arachidonic acid to the cyclic prostaglandins (PGs) $\mathrm{G}_{2}$ and $\mathrm{H}_{2}$, which are further converted to $\mathrm{PGE}_{2}, \mathrm{PGD}_{2}$,

\footnotetext{
${ }^{a}$ Department of Pharmaceutical Chemistry, Institute of Pharmacy, Center for Molecular Biosciences Innsbruck, University of Innsbruck, CCB - Centrum for Chemistry and Biomedicine, Innrain 80-82, 6020 Innsbruck, Austria.

E-mail: ronald.gust@uibk.ac.at; Tel: +43-512-507-58200

${ }^{b}$ Immunobiology and Stem Cell Laboratory, Department of Internal Medicine V (Hematology and Oncology), Innsbruck Medical University, Anichstrasse 35, 6020 Innsbruck, Austria

${ }^{c}$ Tyrolean Cancer Research Institute, Innrain 66, 6020 Innsbruck, Austria

$\dagger$ Electronic supplementary information (ESI) available: Synthesis and characterization of intermediate products; graphic presentation of crystal violet proliferation assay (HT-29, MDA-MB-231, MCF-7); graphic presentation of caspase-3/7 induction at concentrations $\leq 40 \mu \mathrm{M}$ (HT-29, MDA-MB-231, MCF-7); tabular data of COX-1/2 inhibition; HPLC chromatograms of stability tests including specifications of solvent gradient; HPLC chromatograms of purity tests; ${ }^{1} \mathrm{H}-\mathrm{NMR}$ spectra, mass spectra and HPLC chromatograms of final products; graphite furnace time-temperature program. See DOI: 10.1039/c7dt04790h $\$$ These authors contributed equally to the publication.
}

$\mathrm{PGI}_{2}$, and thromboxane via their respective synthases. The constitutively active isoform COX-1 is responsible for basal PG synthesis in nearly all human tissues. Besides their functions in platelet activity, reproduction, and regulation of peripheral vascular resistance, COX-1-derived PGs are particularly important in the maintenance of the protecting gastric mucosa. ${ }^{1,2}$ The second short-living isoform COX-2 is basally expressed only in the central nervous system, the kidney and in female reproduction organs. However, it is inducible upon stimulation by cytokines, endotoxins, and mitogens in the context of pathophysiological processes and contributes via specific PG production to inflammation and carcinogenesis. ${ }^{3-6}$ COX-2 is upregulated in various types of cancer, such as colon and breast cancer, osteosarcoma, chronic myeloid leukemia, melanoma, ovarian, and gastric cancer. ${ }^{7-10}$ Its downstream product $\mathrm{PGE}_{2}$ acts as harmful mediator in cancer tissue. $\mathrm{PGE}_{2}$ inhibits apoptosis, increases proliferation, initiates angiogenesis, supports invasiveness and suppresses immune answer via interaction with its specific receptors $\mathrm{EP}_{1-4}$, leading overall to accelerated tumor growth and increased tumor aggressiveness. ${ }^{11-14}$ 
The cancer chemopreventative and adjuvant chemotherapeutic properties of COX inhibitory nonsteroidal anti-inflammatory drugs (NSAIDs) have therefore been extensively explored in cancers expressing the enzyme. Acetylsalicylic acid (ASS) exhibited good results in the prevention of both breast and colon cancers or as adjuvant in combination therapy. ${ }^{15-18}$ But to the best of our knowledge it does not cause any cytotoxic effect in vitro or solely administered in vivo.

In our group, we tried to increase the antitumor activity of ASS by coordinating it to an organometallic moiety. For this purpose, ASS was esterified with propargyl alcohol and bound to dicobalthexacarbonyl. ${ }^{19}$ The resulting [(prop-2-ynyl)-2-acetoxybenzoate]dicobalthexacarbonyl (Co-ASS) showed considerable growth inhibitory potential in colon (HT-29) and breast (MDA-MB-231) cancer cell lines with $\mathrm{IC}_{50}$ values in the low micromolar range. Compared to ASS, the potency to inhibit COX isoenzymes 10-fold increased for both COX-1 and COX-2, suggesting an interference with the arachidonic acid cascade as a probable mode of action. ${ }^{20}$ However, the high inhibitory effect on COX-1 points to therapy-limiting side effects, such as ulcers, which can be reduced by shifting the COX isoenzyme selectivity towards COX-2. ${ }^{21}$

The amino acids Ile523, His513, and Ile434 in COX-1 lead to a smaller binding cave compared to COX-2 (Val523, Arg513, and Val434). Especially, Ile523 in COX-1 blocks the access to a small hydrophilic side pocket. The larger substrate channel in COX-2 was already utilized to design COX-2 selective NSAIDs. ${ }^{1,22-24}$

Therefore, we tried to use these differences in the volume of the binding pocket to reduce the COX-1 inhibitory effects and to maintain the activity at COX-2 by introduction of a bulkier chlorine substituent into the aromatic moiety of Co-ASS. The derivatives 3-Cl-Co-ASS, 4-Cl-Co-ASS, 5-Cl-Co-ASS, and 6-Cl-Co-ASS were investigated for COX inhibitory effects at isolated or human recombinant isoenzymes and in cell culture experiments against HT-29, MDA-MB-231, and MCF-7 cells regarding their influence on proliferation, metabolic activity, and caspase-3/7 induction. Furthermore, we studied their potential to inhibit intracellular $\mathrm{PGE}_{2}$ production in HT-29 cells and the time-dependent cellular uptake was monitored to complete the characterization of their pharmacological profiles. Finally, the selectivity of the compounds towards cancer cells was investigated using the healthy (non-cancerous) human bone marrow stromal cell line HS-5 for comparison.

\section{Results and discussion}

\section{Synthesis}

6-Chlorosalicylic acid (6-Cl-SS) was obtained by reacting 2-chloro-6-fluorobenzoic acid with powdered sodium hydroxide in dimethyl sulfoxide (DMSO). Thereby, the fluorine substituent was selectively exchanged by a hydroxyl group (Scheme 1). ${ }^{25}$ 3-Chlorosalicylic acid (3-Cl-SS), 4-chlorosalicylic acid (4-Cl-SS), and 5-chlorosalicylic acid (5-Cl-SS) were commercially available.
Acetylation of the chlorine-substituted salicylic acids with acetic anhydride and triethylamine (TEA) in tetrahydrofuran (THF) resulted in the respective chlorine-substituted acetylsalicylic acids (3/4/5/6-Cl-ASS), which were subsequently esterified with propargyl alcohol (leading to propargyl-3/4/5/ 6-Cl-ASS) according to a method described by Steglich et al. using $N, N^{\prime}$-dicyclohexylcarbodiimide (DCC) and the Steglich-catalyst 4 -(dimethylamino)pyridine (DMAP). ${ }^{26}$ Propargylchlorosalicylates, which were built as by-products in this reaction were reacetylated as described above without separation from the respective ASS ester (Scheme 1).

Finally, reaction of the propargyl-3/4/5/6-chloroacetylsalicylates with dicobaltoctacarbonyl in dry THF under an argonmodified atmosphere yielded the respective dicobalthexacarbonyl complexes (Scheme 1).

\section{Biological evaluation}

COX-1/2 isoenzyme inhibition. ASS was used as a positive control and tested for COX-1/2 inhibition. At $10 \mu \mathrm{M}$ only a marginal reduction of enzymatic activity was determined at COX-1 (28.8\%), while it was completely inactive at COX-2 $(0.6 \%)$. In a 10 -fold higher concentration $(100 \mu \mathrm{M})$, the inhibitory properties increased to $73.3 \%$ (COX-1) and $59.4 \%(\mathrm{COX}-2)$ (Table 1). These results go along with results that have been published previously by our group. ${ }^{20,27}$

A chlorine substituent at position 3 or 6 reduced the COX inhibition of ASS to about $30 \%(100 \mu \mathrm{M})$ at both isoenzymes, while substitution at position 4 or 5 maintained the inhibitory effects nearly unchanged (see Table S1 in ESI $\dagger$ ). After esterification of the Cl-ASS moiety with propargyl alcohol, the activity was about $30 \%$ at COX-1 and about $50 \%$ at COX-2, independent of the position of the chlorine substituent at ASS. The COX-2 inhibition induced by the unsubstituted propargyl-ASS was slightly weaker $(34.5 \%)$. Binding of propargyl-ASS to dicobalthexacarbonyl, resulting in Co-ASS, distinctly increased the COX inhibitory effects. An inhibition of about $80 \%$ was determined at both isoenzymes at $10 \mu \mathrm{M}$. Interestingly, the activity of the chlorine-substituted propargyl-ASS derivatives at COX-1 cannot be increased upon coordination. At COX-2, however, all chlorinated Co-ASS derivatives showed the same effects as the parent compound Co-ASS. This finding clearly documents that chlorine substituents reduced the unwanted COX-1 inhibition and shifted therefore the selectivity to COX-2.

COX-1/2 expression in tumor cells. For the interpretation of the results and the discussion about the participation of COX inhibition in the mode of action, all cell lines used for biological investigations within this project were characterized for COX-1 and COX-2 expression levels with TaqMan ${ }^{\circledR}$ quantitative real time polymerase chain reaction (qPCR). From the $C_{\mathrm{q}}$ value of each sample, which is calculated from the point at which the curvature of the amplification curve is maximal, an absolute value of copy numbers was calculated using a standard curve. Before calculation, all values were normalized to the housekeeper gene $\beta$-actin. The results are depicted in Fig. 1.

The MDA-MB-231 (breast cancer) and the HT-29 (colon carcinoma) cell lines express both COX-1 and COX-2, though at 


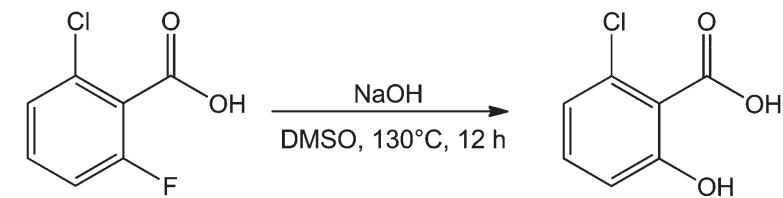

6-Cl-SS<smiles>C#CCOC(=O)c1ccc(Cl)cc1O</smiles><smiles>O=C(O)c1ccc(Cl)cc1O</smiles><smiles>CC(=O)Oc1ccc(Cl)cc1C(=O)O</smiles>

3/4/5/6-Cl-SS<smiles>CC(=O)Oc1ccc(Cl)cc1C(=O)OCC#CC(=O)OC(C)(C)C</smiles>

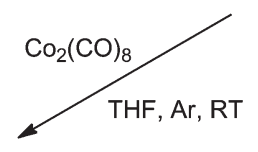<smiles>C#CCOC(=O)c1ccc(Cl)cc1OC(C)=O</smiles>

3/4/5/6-Cl-Co-ASS

Scheme 1 Synthesis of the propargyl-3/4/5/6-chloroacetylsalicylates and related dicobalthexacarbonyls. Ar, argon; DCC, N,N'-dicyclohexylcarbodiimide; DCM, dichloromethane; DMAP, 4-(dimethylamino)pyridine; DMSO, dimethyl sulfoxide; RT, room temperature; TEA, triethylamine; THF, tetrahydrofuran.

Table 1 Inhibition of isolated ovine COX-1 and human recombinant COX-2 isoenzymes

\begin{tabular}{lll}
\hline Compound & $\begin{array}{l}\text { COX-1 } \\
{[\%]}\end{array}$ & $\begin{array}{l}\text { inhibition } \\
\end{array}$ \\
\hline ASS $[10 \mu \mathrm{M}]$ & $\begin{array}{l}\text { COX-2 } \\
{[\%]}\end{array}$ \\
ASS $[100 \mu \mathrm{M}]$ & $28.8 \pm 3.7$ & $0.6 \pm 2.8$ \\
Propargyl-ASS $[100 \mu \mathrm{M}]$ & $73.3 \pm 8.7$ & $59.4 \pm 8.7$ \\
3-Cl-ASS [100 $\mu \mathrm{M}]$ & $25.4 \pm 4.4$ & $34.5 \pm 4.2$ \\
Propargyl-3-Cl-ASS $[100 \mu \mathrm{M}]$ & $27.0 \pm 6.1$ & $29.5 \pm 3.5$ \\
Co-ASS $[10 \mu \mathrm{M}]$ & $32.5 \pm 1.9$ & $52.2 \pm 5.7$ \\
3-Cl-Co-ASS $[10 \mu \mathrm{M}]$ & $82.7 \pm 3.2$ & $78.5 \pm 6.1$ \\
4-Cl-Co-ASS $[10 \mu \mathrm{M}]$ & $24.9 \pm 2.6$ & $71.4 \pm 8.3$ \\
5-Cl-Co-ASS $[10 \mu \mathrm{M}]$ & $22.9 \pm 1.7$ & $69.9 \pm 2.7$ \\
6-Cl-Co-ASS $[10 \mu \mathrm{M}]$ & $25.0 \pm 1.0$ & $64.0 \pm 7.5$ \\
\end{tabular}

${ }^{a}$ Values are represented as \% COX inhibition calculated from initial activity of vehicle treated enzyme. Each experiment was conducted $\geq 3$ times independently and the values are presented as mean $\pm \mathrm{SD}$.

different levels. The highest COX-1/2 expression was found in HT-29 cells. In MDA-MB-231 cells, total copy numbers per $\mu \mathrm{g}$ are only the half compared to HT-29 cells. This is the conse-

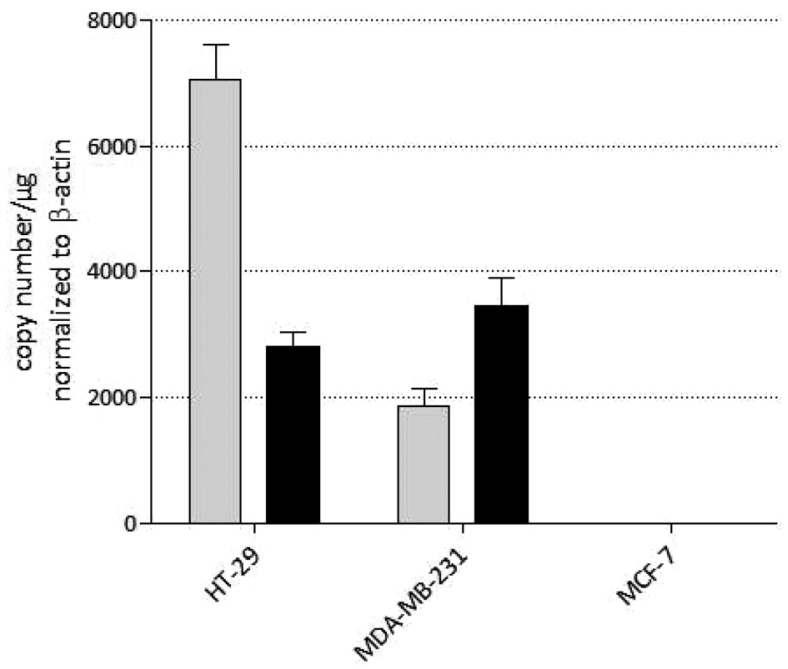

Fig. 1 COX-1 $(\square)$ and COX-2 ( $\square)$ expression of the cell lines HT-29, MDA-MB-231, and MCF-7. Quantification was performed with a TaqMan ${ }^{\circledR}$ qPCR using $\beta$-actin as internal normalization standard. Absolute values were calculated with the standard curve method and represent the mean \pm SD of 3 independent experiments. 
Table 2 Inhibition of cell growth determined in a crystal violet cell biomass assay

\begin{tabular}{llll}
\hline & \multicolumn{3}{c}{$\mathrm{IC}_{50}[\mu \mathrm{M}]$} \\
\cline { 2 - 4 } Compound & HT-29 & MDA-MB-231 & MCF-7 \\
\hline ASS & $\geq 100$ & $\geq 100$ & $\geq 100$ \\
Propargyl-ASS & $\geq 100$ & $\geq 100$ & $\geq 100$ \\
3-Cl-Co-ASS & $2.67 \pm 0.47$ & $8.04 \pm 0.30$ & $22.9 \pm 1.9$ \\
4-Cl-Co-ASS & $1.51 \pm 0.12$ & $5.24 \pm 0.33$ & $15.2 \pm 1.3$ \\
5-Cl-Co-ASS & $2.04 \pm 0.11$ & $7.85 \pm 0.93$ & $20.7 \pm 2.9$ \\
6-Cl-Co-ASS & $21.1 \pm 4.0$ & $22.4 \pm 1.7$ & $41.2 \pm 3.2$ \\
Co-ASS & $1.15 \pm 0.10$ & $10.1 \pm 0.6$ & $16.4 \pm 1.4$ \\
Cisplatin & $3.52 \pm 0.48$ & $3.57 \pm 1.06$ & $4.02 \pm 1.11$
\end{tabular}

$\mathrm{IC}_{50}$ values are calculated as the concentration where $50 \%$ of the compounds maximum antiproliferative activity compared to the vehicle treated control were achieved and are presented as mean \pm SD of $\geq 4$ independent experiments.

quence of a distinctly reduced COX-1 level. The expression of COX-2 is comparable in both cell lines. Interestingly, the MCF-7 cell line used in this study is negative for both, COX-1 and COX-2, and allows therefore the monitoring of possible COX independent cytotoxic effects.

Antiproliferative effects. The antiproliferative activity of the newly synthesized compounds was analyzed in vitro using an already published crystal violet assay. ${ }^{28}$ In this assay the cell mass reduced by the compounds is measured as parameter.

The precursors (ASS and propargyl-ASS derivatives), the chlorine-substituted complexes, and Co-ASS were screened against the HT-29, MDA-MB-231, and MCF-7 cell lines. Cisplatin was used as positive control. The $\mathrm{IC}_{50}$ values presented in Table 2 were determined after an incubation period of $72 \mathrm{~h}$. Concentration-activity curves are submitted as ESI. $\dagger$ As expected, ASS and propargyl-ASS were inactive up to a concentration of $100 \mu \mathrm{M}$. All precursors were excluded from the extended studies on metabolic activity and apoptosis because chlorination of the ASS and the propargyl-ASS moiety did not increase the antiproliferative effects.

Cisplatin showed comparable activity at all cell lines with $\mathrm{IC}_{50}$ values of about 3.5-4.0 $\mu \mathrm{M}$.

The activity of the dicobaltcarbonyl complexes correlates with the total COX level in the cells: the higher the COX level the higher the sensitivity of cell against the compounds. For instance, the lead compound Co-ASS was highly active against HT-29 cells $\left(\mathrm{IC}_{50}=1.15 \mu \mathrm{M}\right)$ but less active against MDA-MB-231 $\left(\mathrm{IC}_{50}=10.1 \mu \mathrm{M}\right)$ and especially MCF-7 $\left(\mathrm{IC}_{50}=\right.$ $16.4 \mu \mathrm{M})$ cells.

After chlorination of the ASS moiety in position 3, 4 or 5, the effects on the HT-29 cell line remained nearly unchanged $\left(\mathrm{IC}_{50}=1.5-2.7 \mu \mathrm{M}\right)$ and slightly decreased against MDA-MB-231 cells in the order Co-ASS $\left(\mathrm{IC}_{50}=10.1 \mu \mathrm{M}\right)<3$-Cl-Co-ASS $\left(\mathrm{IC}_{50}=\right.$ $8.04 \mu \mathrm{M}) \approx 5$-Cl-Co-ASS $\left(\mathrm{IC}_{50}=7.85 \mu \mathrm{M}\right)<4$-Cl-Co-ASS $\left(\mathrm{IC}_{50}=\right.$ $5.24 \mu \mathrm{M})$. In contrast, the 6-chloro derivative was considerably less potent with $\mathrm{IC}_{50} \approx 22 \mu \mathrm{M}$ at both cell lines.

The 3-, 4-, and 5-Cl-substituted complexes and also Co-ASS showed distinctly weaker antiproliferative effects in MCF-7 cells (highest concentration tested: $40 \mu \mathrm{M}$ ) with $\mathrm{IC}_{50}$ values ranging from 15.2 to $22.9 \mu \mathrm{M}$. This finding is an indication but not the proof that COX-1 and COX-2 inhibition are involved in the mode of action. However, the 6-Cl-substituted compound $\left(\mathrm{IC}_{50}=41.2 \mu \mathrm{M}\right)$ displayed a far smaller effect in comparison to the other derivatives.

The determined effects against COX-negative MCF-7 cells demonstrate the interference in further pathways in the cells. Therefore, the growth inhibitory potency cannot be discussed in relation to the COX-1/2 inhibition only. Further parameters must be taken into consideration. This is especially true for 6-Cl-Co-ASS, which was the complex with the lowest antiproliferative effect, while being equally potent as the other complexes in the COX-1/2 assay at isolated enzymes.

Stability studies. For Co-ASS a possible mode of action includes acetylation of the COX enzymes. ${ }^{20}$ If the acetyl group is cleaved in aqueous solution before entering the cells, the resulting salicylic acid derivative might be less active. The incubation time in the cell-based crystal violet assay is $72 \mathrm{~h}$ and allows a possible deacetylation of the complexes, probably influenced by the chlorine substituent at positions $3,4,5$, or 6. Decomposition in the COX assay is not very likely because of an incubation time of only $10 \mathrm{~min}$.

In order to study the influence of the chlorine substituents on the stability in aqueous solution, the ASS derivatives and the ASS-propargyl esters were dissolved in 30\% DMSO/0.1 M phosphate buffer ( $\mathrm{pH} 7.4$ ) to a concentration of $0.5 \mathrm{mg} \mathrm{mL}$ and analyzed time-dependently for degradation at $37{ }^{\circ} \mathrm{C}$ by HPLC analysis. This mixture was used to guarantee that educts and all degradation products remain in solution. Unfortunately, the solubility of the respective cobalt complexes was not high enough to study them under in vitro conditions.

The position of the chlorine substituent at the aromatic moiety strongly influenced the deacetylation. If the substituent is located at position 4 or 5 , the acetylsalicylic ester degraded into the salicylic acid (SS) with $t_{1 / 2}=8.5 \mathrm{~h}$ and $12.5 \mathrm{~h}$, respectively.

The 3-chloro and 6-chloro derivatives were much more stable $\left(t_{1 / 2}(3\right.$-Cl-ASS $)=32.5 \mathrm{~h} ; t_{1 / 2}(6$-Cl-ASS $\left.)=41.7 \mathrm{~h}\right)$.

If the propargyl esters were comparably incubated, ASS, SS, and the SS-propargyl ester were identified as degradation products. The stability increased about 1.5-fold upon esterification to the propargyl ester in the case of the 3-, 4-, and 5-Clsubstituted compounds $\left(t_{1 / 2}\right.$ (propargyl-3-Cl-ASS $)=53.1 \mathrm{~h}$; $t_{1 / 2}($ propargyl-4-Cl-ASS $)=13.5 \mathrm{~h} ; t_{1 / 2}$ (propargyl-5-Cl-ASS $)=$ $19.0 \mathrm{~h})$. A very contrary result was obtained after condensation of 6-Cl-ASS with propargyl alcohol. The half-life decreased from $41.7 \mathrm{~h}$ to $7.9 \mathrm{~h}$. After $48 \mathrm{~h}$ the 6-ASS propargyl ester was completely hydrolyzed. In contrast to the other derivatives, the hydrolysis of the propargyl ester was preferred and the cleavage of the acetyl group played a subordinate role.

Although 6-Cl-Co-ASS could not be investigated under comparable conditions, it can be assumed that it is hydrolyzed into 6-Cl-ASS and propargyl- $\mathrm{Co}_{2}(\mathrm{CO})_{6}$ to a higher extent prior to uptake into cells compared to all other compounds. 
The high-performance liquid chromatography (HPLC) chromatograms are submitted as ESI. $\dagger$

Metabolic activity. The metabolic activity of the cells treated with the cobalt complexes was assessed in a modified MTT (3-(4,5-dimethylthiazol-2-yl)-2,5-diphenyltetrazolium bromide) colorimetric assay. The capability of $\mathrm{NAD}(\mathrm{P}) \mathrm{H}$-dependent cellular oxidoreductase enzymes, which correlates with the number of viable cells, is determined via reduction of the tetrazolium dye MTT to its insoluble, purple colored formazan. Hence, this assay discriminates between living and dead/apoptotic/necrotic cells.

In HT-29 cells, 4-Cl-Co-ASS, and Co-ASS reduced the metabolic activity to approximately $50 \%$ at $20 \mu \mathrm{M}$. 5-Cl-Co-ASS was more active and reduced the metabolic activity at $20 \mu \mathrm{M}$ to $24 \%$ and at $40 \mu \mathrm{M}$ to $6 \%$, while the 3 -chloro derivative decreased the activity at these concentrations only to $69 \%$ $(20 \mu \mathrm{M})$ and $27 \%(40 \mu \mathrm{M})$, respectively. 6-Cl-Co-ASS was completely inactive (Fig. 2a).

In MDA-MB-231 cells nearly the same tendency was observed: 5 -Cl-Co-ASS $>$ Co-ASS $\approx$ 3-Cl-Co-ASS $>$ 4-Cl-Co-ASS >
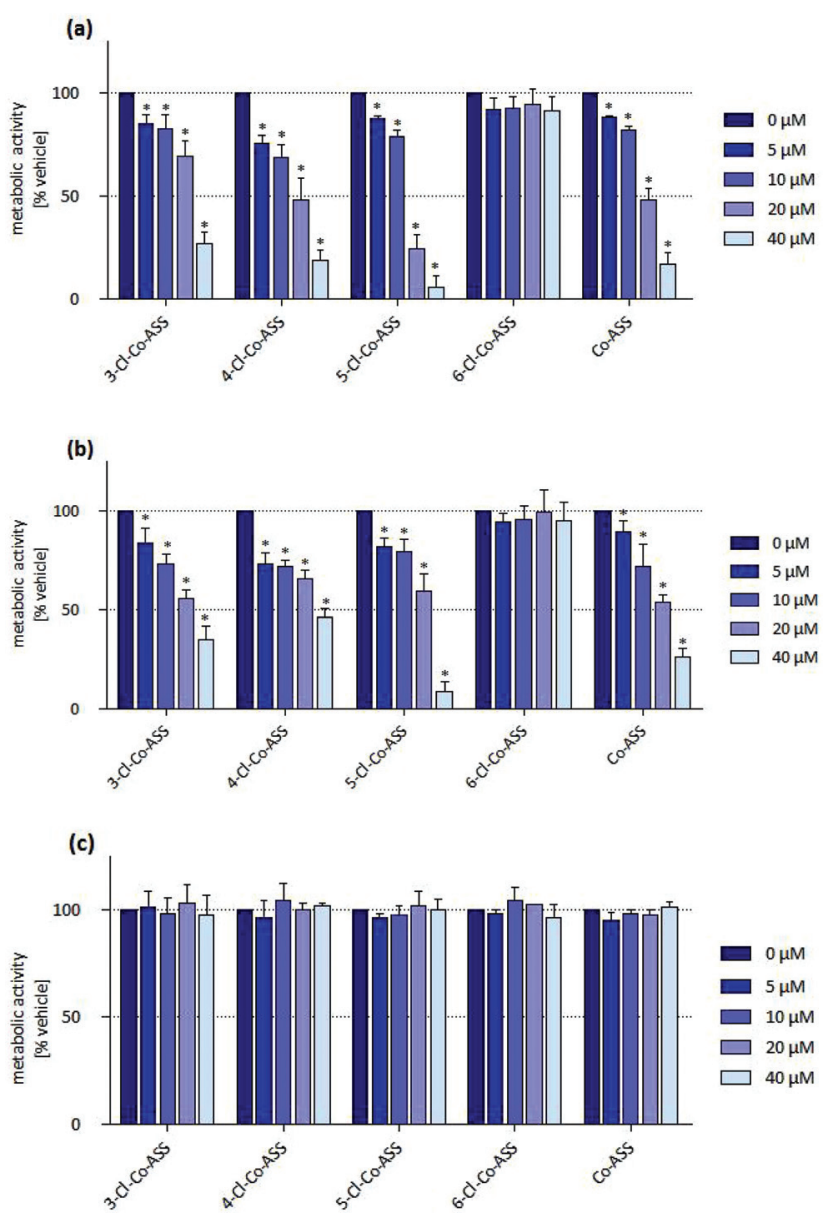

Fig. 2 Effect of cobalt complexes on metabolic activity after $72 \mathrm{~h}$ determined in a MTT assay in (a) HT-29, (b) MDA-MB-231, and (c) MCF-7 cells. Values represent the mean \pm SD of $\geq 4$ independent assays. Asterisks represent statistical significance ( $p<0.05$ vs. controls).
6-Cl-Co-ASS (Fig. 2b). As against HT-29 cells, 6-Cl-Co-ASS was inactive. 5-Cl-Co-ASS as most active complex reduced the metabolic activity to $60 \%(20 \mu \mathrm{M})$ and $10 \%(40 \mu \mathrm{M})$ documenting that MDA-MB-231 cells are slightly less sensitive to the chlorine-substituted compounds.

Interestingly, the metabolic activity of the MCF-7 cells was not significantly affected by any cobalt complex (Fig. 2c), not even at the highest concentration $(40 \mu \mathrm{M})$ used.

In summary, cells expressing COX-1/2 (HT-29, MDAMB-231) were more sensitive against the cobalt complexes than the cell line lacking COX-1/2 (MCF-7). It should be noted, that the metabolic activity is reduced in all cell lines only at relatively high concentrations, which were far above the $\mathrm{IC}_{50}$ value determined in the proliferation assay. These findings suggest that the cobalt complexes have a cytostatic effect on the cells already at low concentrations without interfering with their mitochondrial metabolic turnover.

Induction of apoptosis. The capacity of the compounds to induce programmed cell death was determined in a caspase-3/7 assay. Both caspases are apoptosis-related cysteine peptidases activated via external or intrinsic signalling pathways with the objective of degrading cell components. In contrast to necrosis, which is a pathophysiological event, apoptosis is the physiological destruction of cells, which might be harmful for the organism.

A significant induction of caspase-3/7 was only observed at a concentration of $40 \mu \mathrm{M}$, why only these data are presented in Fig. 3. Further data are available as ESI. $\dagger$

In accordance with the results of the MTT assay, in MCF-7 cells the cobalt complexes only marginally induced caspase-3/ 7-related apoptosis. In MDA-MB-231 and HT-29 cells, 3-, 4-, and 5-Cl-Co-ASS as well as Co-ASS increased the caspase-3/7 content 3- to 5-fold independent on the position of the chlorine substituent.

In general, the caspase-3/7-inductive effect was more pronounced in HT-29 cells compared to the MDA-MB-231 cell line. These data correlate with the results of the MTT assay.

It is obvious that Co-ASS and its chlorine derivatives show cytostatic activity at concentrations $<20 \mu \mathrm{M}$ as the cells neither lose their metabolic capacity nor migrate to an apoptotic state.

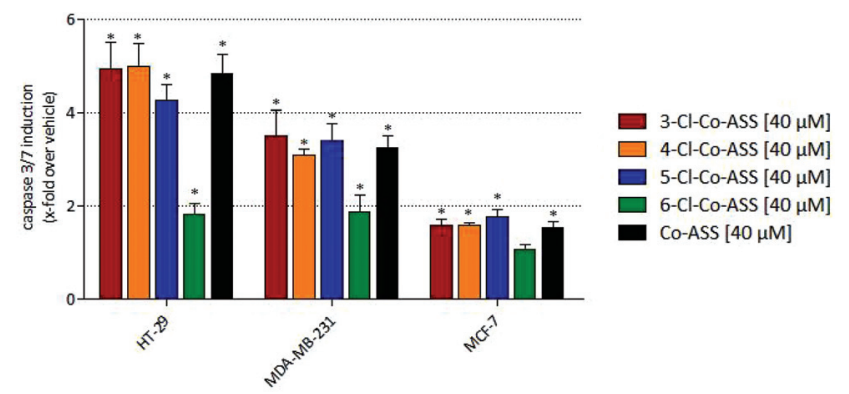

Fig. 3 Induction of caspase-3/7 in HT-29, MDA-MB-231, and MCF-7 cell lines treated with the cobalt complexes. Values represent the mean \pm SD of $\geq 4$ independent assays. Asterisks represent statistical significance ( $p<0.05$ vs. controls). 
$\mathbf{P G E}_{2}$ inhibition. HT-29 cells were selected for investigations of the cellular COX inhibition. These cells express the highest amounts of COX-1/2 and thus represent an established model for the determination of intracellular $\mathrm{PGE}_{2}$ synthesis via EIA.

COX-1/2 catalyze the double oxygenation of added arachidonic acid to $\mathrm{PGG}_{2}$ and the subsequent reduction to $\mathrm{PGH}_{2}$ by its peroxidase (POX) active site. $\mathrm{PGH}_{2}$ is then converted to $\mathrm{PGE}_{2}$ by tissue- and cell-specific isomerases. $\mathrm{PGE}_{2}$ is relatively stable upon release of the cell to the medium and is therefore a good analyte to quantify the arachidonic acid turnover by COX-1/2. Results of this assay are presented in Fig. 4.

Treatment of HT-29 cells with ASS reduced the intracellular $\mathrm{PGE}_{2}$ synthesis $(25.4 \%)$ only at $100 \mu \mathrm{M}$. The respective propargyl ester (ASS-propargyl) caused marginal $\mathrm{PGE}_{2}$ inhibition $(18 \%)$ at $10 \mu \mathrm{M}$. Coordination to $\mathrm{Co}_{2}(\mathrm{CO})_{6}$ led to the lead structure Co-ASS, which is the most active compound in this study $(57.5 \%$ at $10 \mu \mathrm{M})$. Chlorine substituents at the aromatic moiety slightly decreased the influence on the $\mathrm{PGE}_{2}$ release if they are in position 3 (37.7\%), 4 (48.5\%), or 5 (41.9\%). 6-Cl-CoASS reduced the $\mathrm{PGE}_{2}$ level only by $18 \%$. These findings correlate well with the results obtained in the other tests against this cell line and clearly point to a participation of COX inhibition in the mode of action. It is worthy to mention that $\mathrm{PGE}_{2}$ inhibition distinctly higher than $20 \%$ is necessary to influence the cell growth because ASS as well ASS-propargyl were inactive and 6-Cl-Co-ASS was only marginally active at the used concentrations.

Cellular uptake. The uptake of a drug into the target cell is a crucial parameter for its activity as the intracellular concentration influences the extent of interaction with the drug targets. To assess the cellular uptake of the alkyne complexes (concentration $10 \mu \mathrm{M}$ ), the cobalt content in HT-29, MCF-7, and MDA-MB-231 cells after set incubation periods was quantified by high-resolution continuum-source atomic absorption spectrometry (HR CS AAS). Results are graphically depicted in Fig. 5.

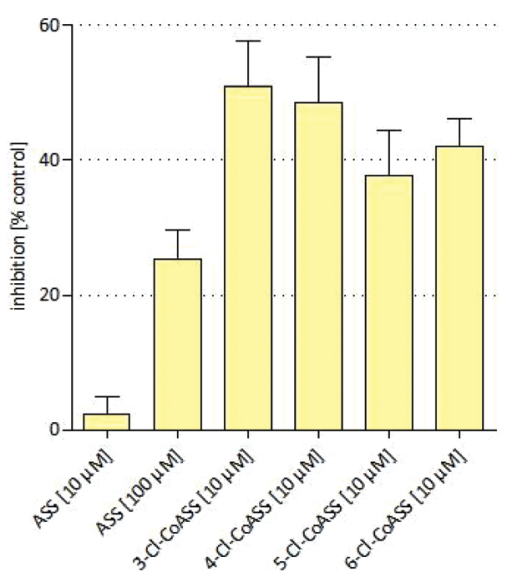

Fig. 4 Inhibition of intracellular $\mathrm{PGE}_{2}$ synthesis assessed in HT-29 colon carcinoma cells treated with ASS and cobalt complexes at $10 \mu \mathrm{M}$. Values represent the mean \pm SD of 3 independent assays.
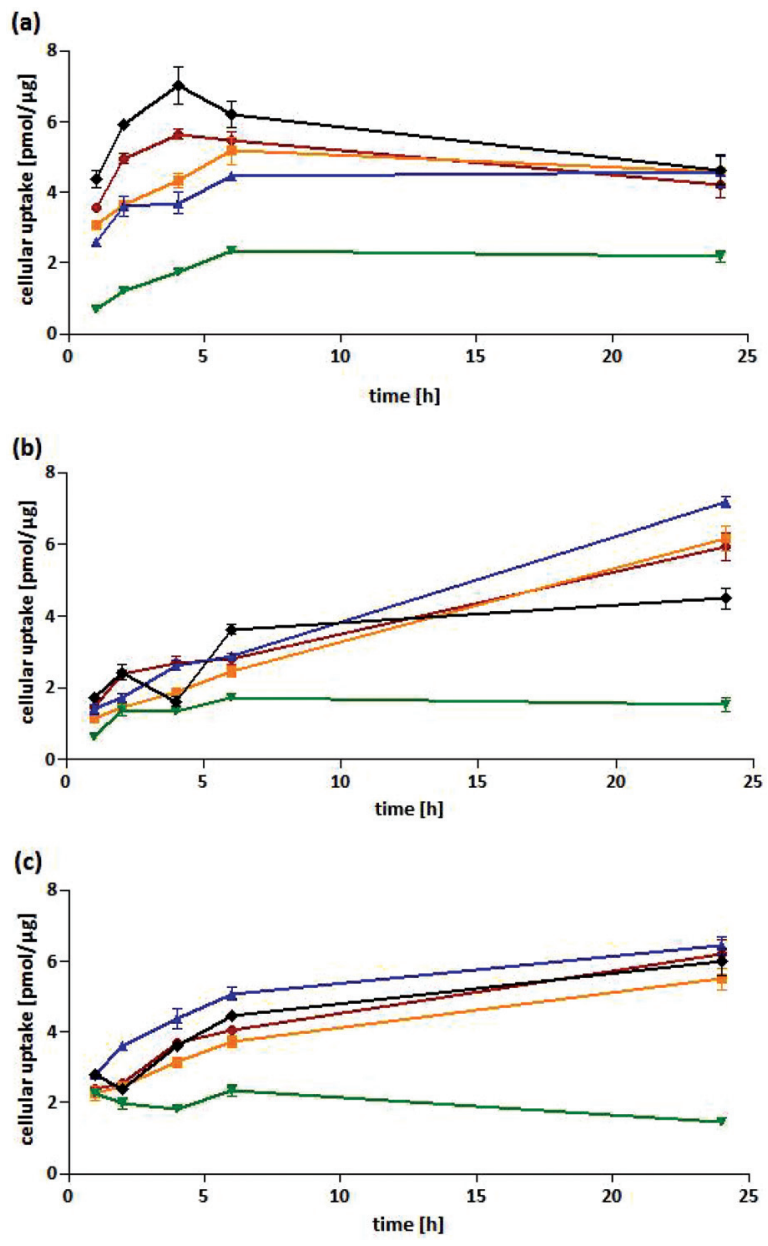

Fig. 5 Determination of cellular uptake (pmol complex per $\mu$ g protein) into (a) HT-29, (b) MDA-MB-231, and (c) MCF-7 after 1, 2, 4, 6, and $24 \mathrm{~h}$ of incubation with 3-Cl-Co-ASS (a), 4-Cl-Co-ASS $(\square), 5-\mathrm{Cl}-\mathrm{Co}-\mathrm{ASS}(\boldsymbol{\Lambda})$, 6 - $\mathrm{Cl}$-Co-ASS $(\nabla)$, Co-ASS $(\diamond)$ at a concentration of $10 \mu \mathrm{M}$. Data points represent mean of 3 independent experiments \pm SE.

Cellular uptake into HT-29 cells. All complexes showed a fast cellular uptake with a maximum after 4-6 h. While the level remained nearly constant for 5-Cl-Co-ASS and 6-Cl-Co-ASS, it slowly decreased for Co-ASS, 3-Cl-Co-ASS as well as 4-Cl-Co-ASS after $6 \mathrm{~h}$ of incubation. After $24 \mathrm{~h}$, with the exception of 6-ClCo-ASS all complexes showed nearly the same cobalt content

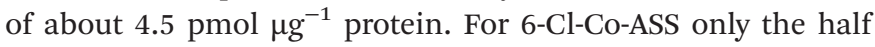
amount was determined $\left(2.2 \mathrm{pmol} \mu \mathrm{g}^{-1}\right)$ and could be the explanation of the lesser $\mathrm{PGE}_{2}$ level measured in the above mentioned $\mathrm{PGE}_{2}$ assay.

Cellular uptake into MDA-MB-231 cells. In MDA-MB-231 cells the complexes were taken up to a lesser extent compared to HT-29 cells during the first $6 \mathrm{~h}$ of incubation. In case of CoASS and 6-Cl-Co-ASS the maximum was reached and the cobalt content did not change during the following $18 \mathrm{~h}$ of incu-

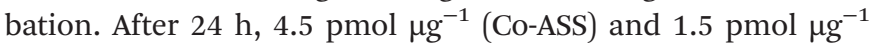
(6-Cl-Co-ASS) were determined. Interestingly, the cobalt amount further increased for 3-Cl-Co-ASS, 4-Cl-Co-ASS, and

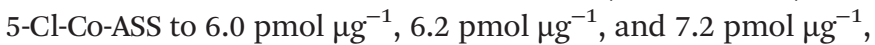




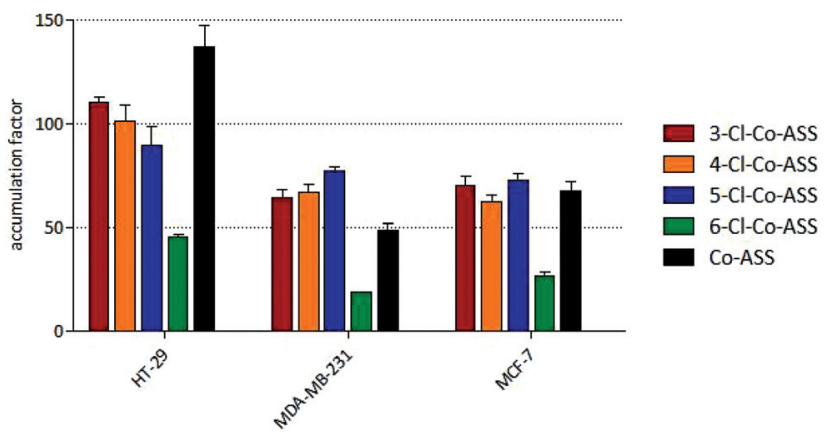

Fig. 6 Maximal accumulation factors of the complexes $(10 \mu \mathrm{M})$ exposed to HT-29, MDA-MB-231, and MCF-7 cells. Values represent the mean \pm SD of 3 independent experiments.

respectively. Saturation could not be observed. After a fast initial uptake within the first 2 h, 3-/4-/5-Cl-Co-ASS displayed nearly linear uptake kinetics expressed by their coefficients of determinations $\left(r^{2}\right)$. The values of $r^{2}$ are $0.9696,0.9982$, and 0.9934 , respectively.

Cellular uptake into MCF-7 cells. Co-ASS and 3/4/5-Cl-Co-ASS revealed in MCF-7 cells comparable uptake profiles. They reached after $6 \mathrm{~h}$ cobalt levels of 3.7-5.1 pmol $\mu^{-1}$, which further increased until the end of the experiment $(24 \mathrm{~h})$. After

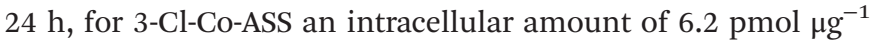
and 4 -Cl-Co-ASS of $5.5 \mathrm{pmol}_{\mu \mathrm{g}}{ }^{-1}$ were measured. The highest

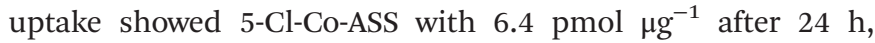
slightly higher than Co-ASS $\left(6.0 \mathrm{pmol} \mu \mathrm{g}^{-1}\right)$. Again, the lowest level was determined for 6-Cl-Co-ASS. Interestingly, it reached the highest level of $2.0 \mathrm{pmol}^{\mathrm{g}} \mathrm{g}^{-1}$ after $2 \mathrm{~h}$ that decreased during the following incubation period to $1.5 \mathrm{pmol}_{\mu \mathrm{g}}^{-1}$.

If the protein contents are correlated with the cell volumes, the accumulation grades can be calculated. ${ }^{29,30}$ Compared to the extracellular concentration of $10 \mu \mathrm{M}$, the complexes were strongly accumulated in the tumor cells (Fig. 6). The highest accumulation grades were measured within $24 \mathrm{~h}$ for 3-/4-/5-ClCo-ASS in HT-29 cells (90- to 110-fold), while MDA-MB-231 and MCF-7 cells accumulated the complexes to a lower extent (64to 77-fold and 62- to 73-fold, respectively). The values of 6-Cl-

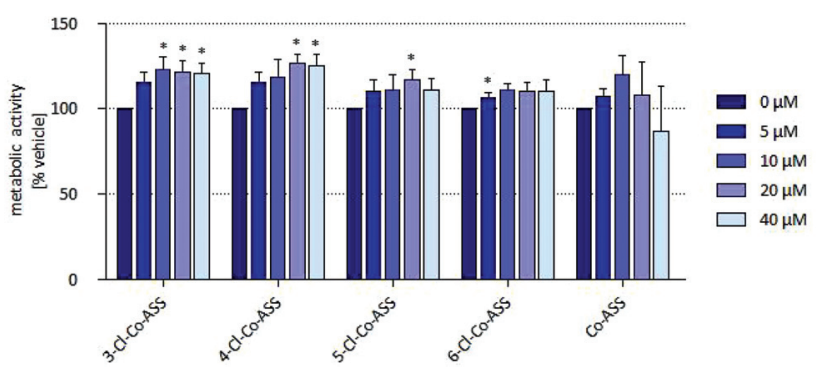

Fig. 7 Effect of cobalt complexes on metabolic activity after $72 \mathrm{~h}$ determined in a MTT assay in HS-5 cells. Values represent the mean \pm SD of $\geq 4$ independent assays. Asterisks represent statistical significance ( $p<0.05$ vs. controls).
Co-ASS are less than $50 \%$ of its derivatives (45-fold, 18 -fold, and 27-fold, respectively).

Metabolic activity in the human bone marrow stromal cell line HS-5. The effects of the Co-ASS derivatives against noncancerous cells were studied exemplarily against the HS-5 cell line. As depicted in Fig. 7, all complexes did not influence the metabolic activity of the HS-5 cells, which points to a selective damage of COX-positive tumor cells (compare Fig. 2 and 7).

\section{Conclusions}

In continuation of our previously published study about the unselective COX-1/2 inhibitor Co-ASS, we synthesized its 3/4/5/ 6-chlorine-substituted derivatives. The aim of this study was to increase the selectivity for the COX-2 isoenzyme. The chlorine substituents at the Co-ASS should utilize on the one hand the larger binding cave of COX-2 to promote activity at this isoenzyme and the other hand they should reduce the binding to COX-1 due to steric repulsion. Indeed, all complexes had high inhibitory potency against isolated COX-2 (60-80\% inhibition at $10 \mu \mathrm{M}$ ) and low effects at COX-1 (about 20\% at $10 \mu \mathrm{M}$ ). Biological effects (inhibition of proliferation and metabolic activity, induction of apoptosis) were only determined in cells with COX expression. Especially the inactivity against COXnegative MCF-7 cell points to an interference in the arachidonic acid oxidation cascade as part of the mode of action. The missing effects of 6-Cl-Co-ASS in cellular systems can be explained by its low stability in aqueous solution and/or by a distinctly reduced cellular uptake. Co-ASS and its Cl-substituted derivatives demonstrated high selectivity against tumor cells, because they were completely inactive at the healthy, non-tumorigenic human bone marrow stromal cell line HS-5.

\section{Experimental section}

\section{General material and methods}

All educts, solvents, and other chemicals were purchased from Sigma-Aldrich, TCI Chemicals, Fluka, or Alfa Aesar. Solvents were purchased in appropriate purity or distilled prior to utilization. Milli-Q water was obtained from a Milli-Q Gradient A10 water purification system (Merck Millipore, Billerica, USA). Column chromatography was performed using silica gel 60 (particle size 40-63 $\mu \mathrm{m}$ ). Thin layer chromatography (TLC) was carried out using Polygram ${ }^{\circledR}$ SIL G/UV254 polyester foils with a $0.2 \mathrm{~mm}$ layer of silica gel with fluorescence indicator (Macherey-Nagel, Düren, Germany). Detection was performed by observation under UV-light at 254 and/or $365 \mathrm{~nm}$. Melting points were measured with a Kofler heatable microscope. ${ }^{1} \mathrm{H}$-Nuclear magnetic resonance spectra $\left({ }^{1} \mathrm{H}\right.$-NMR-spectra) were recorded using a Gemini 2000 NMR Spectrometer (Varian, Palo Alto, USA, now part of Agilent Technologies, Santa Clara, USA) at $200 \mathrm{MHz}$ in DMSO- $_{6}$ with tetramethylsilane as internal standard. Chemical shifts are given in parts per million (ppm). Coupling constants are given in Hertz $(\mathrm{Hz})$. 
High resolution mass spectrometry (HR-MS) was performed using an Orbitrap Elite (Thermo Fisher Scientific, Waltham, USA). Infrared (IR) spectra were recorded using an Alpha FT-IR Spektrometer (Bruker, Billerica, USA). HPLC measurements were conducted with an instrument from Shimadzu (Duisburg, Germany) equipped with an autosampler SIL-20A HT, a pump LC20 AD, a column oven CT0-10AS VP and a diode-array detector SPD-M20A with a deuterium and tungsten lamp. Separation was performed over an Eurospher 100-5 C18 (250× $4 \mathrm{~mm}$ ) column (Knauer, Berlin, Germany). Purity of all final products was above 95\%. Absorbance and luminescence in biological assays were measured with an Enspire multimodal plate reader (PerkinElmer Life Sciences, Waltham, USA).

\section{Chemistry}

General procedure for the synthesis of alkinyl cobalt complexes. $50 \mathrm{mg}$ ( $0.2 \mathrm{mmol})$ of propargyl-Cl-ASS was dissolved in anhydrous THF and put into a three-necked-flask, equipped with an argon connection, a condenser with a bubble counter and a plug. $71 \mathrm{mg}$ ( $0.21 \mathrm{mmol}, 1.05$ equivalent) of dicobaltoctacarbonyl were quickly weighed in a dry weighing dish and added to the reaction mixture, which was subsequently stirred for $4 \mathrm{~h}$ at room temperature. The reaction solution turned to reddish and evolution of carbon monoxide was observed during the first minutes. Reaction was stopped by adding approximately $1 \mathrm{~g}$ of silica gel. The solvent was evaporated under reduced pressure. Purification was carried out by column chromatography using silica gel, with petroleum/ethyl acetate $(9: 1)$ as eluent. The coloured fractions were collected. The first fraction contained the alkinyl cobalt complex of the salicylic acid derivative and the second one contained the chloroacetylsalicylic acid ester cobalt complex.

[2-Acetoxy-3-chloropropargylbenzoate]dicobalthexacarbonyl (3-Cl-Co-ASS). Red crystals; yield: $0.052 \mathrm{~g}$ (0.096 mmol, 48.8\%); $\mathrm{mp}>150{ }^{\circ} \mathrm{C} .{ }^{1} \mathrm{H}-\mathrm{NMR}\left(200 \mathrm{MHz}, \mathrm{CDCl}_{3}\right): \delta 7.98$ (d, 1H, ArH-6), 7.64 (d, 1H, ArH-4), 7.22 (dd, 1H, ArH-5), 6.12 (s, 1H, CH), 5.48 (s, $\left.1 \mathrm{H}, \mathrm{CH}_{2}\right), 2.41$ (s, 3H, $\left.\mathrm{CH}_{3}\right)$; IR $\left(\nu \mathrm{cm}^{-1}\right)$ : $3091 \mathrm{w}$ (Aryl-C-H), 2917 w, 2852 w (C-H), 2094 m, 2012 s, 2001 s (C三C), 1775 s, $1719 \mathrm{~s}(\mathrm{C}=\mathrm{O}), 1595 \mathrm{~m}, 1572 \mathrm{w}(\mathrm{C}=\mathrm{C}), 1364 \mathrm{~m}\left(\delta-\mathrm{CH}_{3}\right), 1251$ s, $1183 \mathrm{~s}, 1105 \mathrm{~s}$ (C-O); HR-MS: $\mathrm{m} / \mathrm{z}$ calculated for $\mathrm{C}_{18} \mathrm{H}_{9} \mathrm{ClCo}_{2} \mathrm{O}_{10}[2 \mathrm{M}+\mathrm{Na}]^{+}:$1098.6892, found: 1098.6979; HPLC [MeOH/water $(70: 30)]$ : purity $99.7 \%$.

[2-Acetoxy-4-chloropropargylbenzoate]dicobalthexacarbonyl (4-Cl-Co-ASS). Red crystals; yield: $0.050 \mathrm{~g}$ (0.093 mmol, 50\%); $\mathrm{mp}>150{ }^{\circ} \mathrm{C} .{ }^{1} \mathrm{H}-\mathrm{NMR}\left(200 \mathrm{MHz}, \mathrm{CDCl}_{3}\right): \delta 8.04$ (s, 1H, ArH-6), 7.28 (s, 2H, ArH-3, ArH-5), 6.12 (s, 1H, CH), 5.47 (s, 1H, $\mathrm{CH}_{2}$ ), 2.36 (s, 3H, $\left.\mathrm{CH}_{3}\right)$; IR $\left(\nu \mathrm{cm}^{-1}\right)$ : $3092 \mathrm{w}$ (Aryl-C-H), $2925 \mathrm{w}, 2852$ w $(\mathrm{C}-\mathrm{H}), 2097 \mathrm{~m}, 2053 \mathrm{~s}, 2006 \mathrm{~s}(\mathrm{C} \equiv \mathrm{C}), 1775 \mathrm{~s}, 1725 \mathrm{~s}(\mathrm{C}=\mathrm{O})$, $1597 \mathrm{~s}, 1568(\mathrm{C}=\mathrm{C}), 1369 \mathrm{~m}\left(\delta-\mathrm{CH}_{3}\right), 1184 \mathrm{~s}, 1092 \mathrm{~s}(\mathrm{C}-\mathrm{O})$; HR-MS: $m / z$ calculated for $\mathrm{C}_{18} \mathrm{H}_{9} \mathrm{ClCo}_{2} \mathrm{O}_{10}[2 \mathrm{M}+\mathrm{Na}]^{+}$: 1098.6892, found: 1098.6977; HPLC [MeOH/water (70:30)]: purity $95.6 \%$.

[2-Acetoxy-5-chloropropargylbenzoate]dicobalthexacarbonyl (5-Cl-Co-ASS). Red crystals; yield: $0.065 \mathrm{~g}$ (0.121 mmol, 61\%); $\mathrm{mp}>150{ }^{\circ} \mathrm{C} .{ }^{1} \mathrm{H}-\mathrm{NMR}\left(200 \mathrm{MHz}, \mathrm{CDCl}_{3}\right): \delta 8.08$ (s, 1H, ArH-6), 7.54 (d, $\left.1 \mathrm{H},{ }^{3} J=7.8 \mathrm{~Hz}, \mathrm{ArH}-4\right), 7.08$ (d, $\left.{ }^{3} J=8.0 \mathrm{~Hz}, 1 \mathrm{H}, \mathrm{ArH}-3\right)$, $6.12(\mathrm{~s}, 1 \mathrm{H}, \mathrm{CH}), 5.47\left(\mathrm{~s}, 1 \mathrm{H}, \mathrm{CH}_{2}\right), 2.35\left(\mathrm{~s}, 3 \mathrm{H}, \mathrm{CH}_{3}\right)$; IR $\left(\nu \mathrm{cm}^{-1}\right): 3128 \mathrm{w}$ (Aryl-C-H), $2962 \mathrm{w}, 2928 \mathrm{w}, 2853 \mathrm{w}(\mathrm{C}-\mathrm{H})$, $2094 \mathrm{~m}, 2026 \mathrm{~s}, 2003 \mathrm{~s}(\mathrm{C} \equiv \mathrm{C}), 1762 \mathrm{~s}, 1730 \mathrm{~s}(\mathrm{C}=\mathrm{O}), 1603 \mathrm{w}$, $1579 \mathrm{w}(\mathrm{C}=\mathrm{C}), 1369 \mathrm{~m}\left(\delta-\mathrm{CH}_{3}\right), 1188 \mathrm{~s}, 1069 \mathrm{~s}(\mathrm{C}-\mathrm{O})$; HR-MS: $m / z$ calculated for $\mathrm{C}_{18} \mathrm{H}_{9} \mathrm{ClCo}_{2} \mathrm{O}_{10}[2 \mathrm{M}+\mathrm{Na}]^{+}:$1098.6892, found: 1098.6980; HPLC [MeOH/water (70:30)]: purity $99.6 \%$.

[2-Acetoxy-6-chloropropargylbenzoate]dicobalthexacarbonyl (6-Cl-Co-ASS). Red crystals; yield: $0.053 \mathrm{~g}$ (0.098 mmol, 50\%); $\mathrm{mp}>150{ }^{\circ} \mathrm{C}$. ${ }^{1} \mathrm{H}-\mathrm{NMR}\left(200 \mathrm{MHz}, \mathrm{CDCl}_{3}\right): \delta 7.39\left(\mathrm{dd},{ }^{3} J=\right.$ $8.4 \mathrm{~Hz}, 1 \mathrm{H}, \operatorname{ArH}-4), 7.33$ (d, $1 \mathrm{H}, \operatorname{ArH}-5), 7.12$ (d, ${ }^{3} J=8.0 \mathrm{~Hz}, 1 \mathrm{H}$, ArH-3), 6.11 (s, 1H, CH), 5.23 (s, 1H, $\left.\mathrm{CH}_{2}\right), 2.28$ (s, 3H, $\left.\mathrm{CH}_{3}\right)$; IR $\left(\nu \mathrm{cm}^{-1}\right): 3094 \mathrm{w}$ (Aryl-C-H), $2959 \mathrm{w}, 2923 \mathrm{w}, 2851 \mathrm{w}(\mathrm{C}-\mathrm{H})$, $2098 \mathrm{~m}, 2054 \mathrm{~s}, 2004 \mathrm{~s}(\mathrm{C} \equiv \mathrm{C}), 1774 \mathrm{~s}, 1736 \mathrm{~s}(\mathrm{C}=\mathrm{O}), 1596 \mathrm{~m}$ $(\mathrm{C}=\mathrm{C}), 1369 \mathrm{~m}\left(\delta-\mathrm{CH}_{3}\right), 1259 \mathrm{~s}, 1183 \mathrm{~m}, 1100 \mathrm{~s}(\mathrm{C}-\mathrm{O})$; HR-MS: $m / z$ calculated for $\mathrm{C}_{18} \mathrm{H}_{9} \mathrm{ClCo}_{2} \mathrm{O}_{10}[2 \mathrm{M}+\mathrm{Na}]^{+}$: 1098.6892, found: 1098.6980; HPLC [MeOH/water $(70: 30)]$ : purity $100 \%$.

\section{Stability studies}

The $0.1 \mathrm{M}$ phosphate buffer was prepared by diluting $2.26 \mathrm{~mL}$ of a $\mathrm{NaH}_{2} \mathrm{PO}_{4} \cdot \mathrm{H}_{2} \mathrm{O}$ solution $\left(13.8 \mathrm{~g} \mathrm{NaH} \mathrm{PO}_{4} \cdot \mathrm{H}_{2} \mathrm{O}\right.$ in $100 \mathrm{~mL}$ of water) and $15.48 \mathrm{~mL}$ of a $\mathrm{Na}_{2} \mathrm{HPO}_{4}$ solution $\left(8.9 \mathrm{~g} \mathrm{Na} \mathrm{HPO}_{4}\right.$ in $100 \mathrm{~mL}$ of water) with water to a final volume of $100 \mathrm{~mL} .5 \mathrm{mg}$ of the test substance were weighed in a $10 \mathrm{~mL}$ volumetric flask, dissolved in $3 \mathrm{~mL}$ of DMSO and filled up with $0.1 \mathrm{M}$ phosphate buffer ( $\mathrm{pH} 7.4$ ) to the mark. A solution of $4.01 \mathrm{mg}$ 5 -chlorosalicylic acid dissolved in $3 \mathrm{~mL}$ of DMSO was filled up to $10 \mathrm{~mL}$ with phosphate buffer and was used as reference solution.

The mobile phase was a two-component solvent (acetonitrile and acetic acid 1\%), which was run in a gradient. The gradient specifications can be found in Table S3 of the ESI. $\dagger$

\section{Biology}

General cell culture methods. The colon cancer cell line HT-29, the hormone-independent breast cancer cell line MDA-MB-231, and the hormone-sensitive breast cancer cell line MCF-7 were obtained from the cell line service (CLS, Eppelheim, Germany). The human bone marrow stromal cell line HS-5 was kindly provided by Dr Karin Jöhrer, Tyrolean Cancer Research Institute. HT-29, MDA-MB-231, and MCF-7 cells were maintained as monolayer cultures in Dulbecco's modified eagle medium (DMEM) without phenol red, with glucose (4.5 $\mathrm{g} \mathrm{L}^{-1}$ ) (GE Healthcare), supplemented with fetal calf serum (FCS; 10\%; Biochrom) and L-glutamine $\left(584 \mathrm{mg} \mathrm{L}^{-1}\right.$, GE Healthcare). The cells were cultivated in a humidified atmosphere (5\% $\mathrm{CO}_{2} / 95 \%$ air) at $37{ }^{\circ} \mathrm{C}$ and passaged twice a week. HS-5 cells were grown in RPMI 1640 without phenol red (PAA Laboratories, Pasching, Austria), supplemented with glutamine (2 mM), penicillin (100 $\left.\mathrm{U} \mathrm{mL} \mathrm{mL}^{-1}\right)$, streptomycin $\left(100 \mu \mathrm{g} \mathrm{mL} \mathrm{m}^{-1}\right)$ and fetal bovine serum (FBS; 10\%; all from Invitrogen Corporation, Gibco, Paisley, Scotland) at $37{ }^{\circ} \mathrm{C}$ in a $5 \% \mathrm{CO}_{2} / 95 \%$ air atmosphere and fed twice weekly. Cell lines were authenticated by typing short tandem repeats and routinely monitored for mycoplasma infection. 
Analysis of relative COX-1 and COX-2 expression. COX-1 and COX-2 expression in tested tumor cell lines was determined via qPCR. Total RNA was isolated with a RNA isolation kit (RNeasy mini Kit) using a QIAshredder for homogenization of the cell lysate (both Qiagen, Hilden, Germany) according to the manufacturer's protocol. The synthesis of cDNA was performed using a High-Capacity cDNA Reverse Transcription Kit (Applied Biosystems, Foster City, USA). Quantification of cDNA was conducted with a qPCR Taqman Assay using a FAMTMlabeled probe (Applied Biosystems) according to the manufacturer's protocol. Amplification was performed with a Lightcycler®96 (Roche Diagnostics, Basel, Switzerland). The housekeeper gene $\beta$-actin was quantified as loading control and for normalization calculations. Samples were measured in triplicate. A sample containing Milli-Q water was run as negative control. $C_{\mathrm{q}}$ values were automatically calculated with the Lightcycler®96 software (Roche Diagnostics). Concentration and purity of RNA and cDNA samples, respectively, were determined with a NanoDrop 2000 UV-vis spectrophotometer (Thermo Fisher, Waltham, USA). COX-1 and COX-2 expression was absolutely quantified with a calibration curve using COX-1 and COX-2 templates (Origene, Rockville, USA) at 0-107 copies per well. Both sample values and calibration curve values were normalized to the $C_{\mathrm{q}}$ value of $\beta$-actin of the respective cell line.

Determination of cell biomass with crystal violet staining. The in vitro testing of the new compounds for their effects on cell biomass was carried out according to a modified protocol previously described. ${ }^{28}$ Cells were seeded in their exponential growth phase in complete DMEM in 96-well microtiter plates $\left(2 \times 10^{3}\right.$ cells per well, $100 \mu \mathrm{L}$ per well $)$ in quadruples. Plates were kept at $37{ }^{\circ} \mathrm{C}$ for $24 \mathrm{~h}$ prior to addition of complete medium containing the vehicle, the positive controls Cisplatin and Co-ASS, and the newly synthesized compounds at indicated concentrations, respectively. After an incubation time of $72 \mathrm{~h}$, medium was aspirated, cells were washed with PBS and fixed with a solution of $1 \%(\mathrm{v} / \mathrm{v})$ glutaric dialdehyde in PBS. Cell biomass was determined via staining of the chromatin of adherent cells with crystal violet, extraction of the stain with ethanol (70\%) and subsequent measurement of absorbance at $590 \mathrm{~nm}$. Mean values $\pm \mathrm{SD}$ of $\geq 4$ independent experiments were calculated and the effects of the compounds were expressed as percentage of the cell mass of a vehicle-treated control, which was set at $100 \%$. The $\mathrm{IC}_{50}$ values were calculated with Prism 7.0 (GraphPad, San Diego, CA) using nonlinear regression and the decadal logarithm of the inhibitor versus variable slope response equation. The top constraint was set to $100 \%$.

Determination of metabolic activity. Exponentially growing cells were seeded in 96-well plates (HT-29, MDA-MB-231, MCF-7: $10^{4}$ cells per well, $50 \mu \mathrm{L}$ per well; HS-5: $2 \times 10^{4}$ cells per well, $50 \mu \mathrm{L}$ per well) in triplicates. Appropriate concentrations of compounds were added $3 \mathrm{~h}$ (HT-5: $1 \mathrm{~h}$ ) thereafter. After a three-day culture at $37{ }^{\circ} \mathrm{C}$ in a $5 \% \mathrm{CO}_{2} / 95 \%$ air atmosphere, cultures were analyzed for metabolic activity using a modified 3-(4,5-dimethylthiazol-2-yl)-2,5-diphenyltetrazolium bromide (MTT) assay (EZ4U kit; Biomedica, Vienna, Austria) according to the manufacturer's instructions. To exclude unspecific staining by FCS-containing medium, the optical density of the respective medium was subtracted. Metabolic activity in the absence of the compound was set at $100 \%$.

Determination of caspase-3/7 induction. Exponentially growing cells were seeded in 96-well plates $\left(5 \times 10^{4}\right.$ cells per well, $50 \mu \mathrm{L}$ per well) in triplicates. The compounds were added in appropriate concentrations after $3 \mathrm{~h}$. After cultivation for $24 \mathrm{~h}$ at $37{ }^{\circ} \mathrm{C}$ in a $5 \% \mathrm{CO}_{2} / 95 \%$ air atmosphere, supernatant was transferred to white 96-well plates and induction of apoptosis was measured by caspase-3/7 detection using a Caspase3/7 Glo® Kit (Promega, Madison, USA) according to the manufacturer's instructions. Values were normalized to luminescence values of medium only. All values were calculated in relation to the caspase-3/7 activity of the untreated cells.

COX inhibition assay. The inhibition of isolated ovine COX-1 and human recombinant COX-2 was determined at $10 \mu \mathrm{M}$ and/or $100 \mu \mathrm{M}$ of the respective compounds by enzyme immunoassay (EIA) (COX Inhibitor Screening Assay, Cayman Chemicals, Ann Arbor, USA) according to the manufacturer's protocol. Isoenzymes were incubated with the respective compound for exactly $10 \mathrm{~min}$. Results were calculated as the mean of duplicate determination and represent the mean \pm SD of $\geq 3$ independent experiments. Untreated control was set to $0 \%$ inhibition.

Determination of inhibition of cellular $\mathrm{PGE}_{2}$ synthesis. HT-29 cells were seeded in 24-well plates $\left(5 \times 10^{4}\right.$ cells per well, $500 \mu \mathrm{L}$ per well) and incubated at $37^{\circ} \mathrm{C}$ for $24 \mathrm{~h}$. After addition of compounds at a concentration of $10 \mu \mathrm{M}$, cells were incubated for another $24 \mathrm{~h}$ at $37{ }^{\circ} \mathrm{C}$ in a $5 \% \mathrm{CO}_{2} / 95 \%$ air atmosphere. Arachidonic acid ( $50 \mu \mathrm{M}$, Sigma-Aldrich, St Louis, USA) was added to the cells and COX-catalyzed enzymatic turnover was stopped $1 \mathrm{~h}$ thereafter by removing the supernatant medium. $\mathrm{PGE}_{2}$ concentration in the supernatant was measured by EIA (Prostaglandin $\mathrm{E}_{2}$ Kit - Monoclonal, Cayman Chemicals) according to the manufacturer's protocol. Results were calculated as the mean of duplicate determination and represent the mean $\pm \mathrm{SD}$ of 3 independent experiments. Untreated control was set to $0 \%$ inhibition of $\mathrm{PGE}_{2}$ synthesis.

Cellular uptake studies. To assess the cellular uptake of the alkyne complexes, the cobalt content in HT-29 colon and MCF-7 as well as MDA-MB-231 breast carcinoma cells was quantified by high-resolution continuum-source atomic absorption spectrometry (HR CS AAS). The cobalt levels were correlated to the protein contents which were measured by application of the Bradford's method. ${ }^{31}$

Cellular uptake studies. Exponentially growing HT-29, MCF-7, and MDA-MB-231 cells, respectively, were seeded in 6-well tissue culture plates in $2 \mathrm{~mL}$ of completed DMEM and incubated at $37{ }^{\circ} \mathrm{C}$ in a $5 \% \mathrm{CO}_{2} / 95 \%$ air atmosphere. The medium was aspirated after $24 \mathrm{~h}$ and completed DMEM containing the respective drug $(10 \mu \mathrm{M})$ or the vehicle DMSO was added. After the appropriate incubation periods ( $1 \mathrm{~h}, 2 \mathrm{~h}, 4 \mathrm{~h}, 6 \mathrm{~h}, 24 \mathrm{~h}$ ), the medium was removed and the cells were detached by washing once with PBS followed addition of accutase (GE Healthcare BioSciences, Pasching, Austria) and harvested by 
collecting them with PBS. The cell suspension was centrifuged (8000 rcf, $3 \mathrm{~min}, \mathrm{RT}$ ) and the supernatant was discarded. The isolated cell pellet was washed with PBS and stored at $-20{ }^{\circ} \mathrm{C}$ until further analysis. Immediately after thawing, the cell pellet was resuspended in twice distilled water and lysed by sonification ( $20 \mathrm{~s}$, nine cycles, $80-85 \%$ power). The cell lysate was appropriately diluted with Triton-X-100 (final concentration: $0.1 \%$ ) and stabilized with $\mathrm{HNO}_{3}$ 13\% (final concentration: $10 \%$ ) to be analyzed for cobalt content by HR CS AAS. The cellular concentration of the compounds is expressed as the amount of compound ( $\mathrm{pmol}$ ) related to cellular protein mass $(\mu \mathrm{g})$. Values were calculated as the mean of 3 independent experiments.

$H R$ CS AAS. For the cobalt quantification, a contrAA 700 high-resolution continuum-source atomic absorption spectrometer (Analytik Jena AG) was employed. Pure samples of the respective complexes were utilized as standards and calibration was conducted in a matrix matched manner. The mean integrated absorbances of triplicate injections were used throughout the studies. Samples were directly injected into coated standard graphite tubes (Analytik Jena AG). The timetemperature furnace program applied for the determination of cobalt was optimized regarding pyrolysis and atomization temperatures. It can be found as ESI (Table $\mathrm{S} 2 \dagger$ ). Cobalt was quantified at a wavelength of $240.7254 \mathrm{~nm}$.

Quantification of protein content. The protein content of cell lysates was quantified by the method of Bradford. ${ }^{31}$ In brief, the lysates were appropriately diluted with twice distilled water. To each $20 \mu \mathrm{L}$ thereof $200 \mu \mathrm{L}$ of Bradford reagent were added respectively in 96-well plates. After incubation for $5 \mathrm{~min}$ at RT, the absorbances were read at $595 \mathrm{~nm}$ in a microplate reader (Thermo Scientific Multiskan GO). Solutions of albumin bovine fraction $\mathrm{V}$ diluted with twice distilled water (31.25-1500 $\mu \mathrm{g} \mathrm{mL}^{-1}$ ) were used as calibration standards. Samples were measured in duplicate.

Statistical analysis. The Wilcoxon rank sum test was used to analyze the significance of differences between cell biomass, proliferation, metabolic activity, and apoptosis induction in the absence and the presence of a variable concentration of the test compounds (NCSS software, Kaysville, UT, USA).

\section{Abbreviations}

\begin{tabular}{|c|c|}
\hline ASS & Acetylsalicylic acid \\
\hline $\operatorname{COX}$ & Cyclooxygenase \\
\hline DMEM & Dulbecco's modified eagle medium \\
\hline DMSO & Dimethyl sulfoxide \\
\hline EIA & Enzyme immunoassay \\
\hline FCS & Fetal calf serum \\
\hline HPLC & High-performance liquid chromatography \\
\hline HR CS AAS & $\begin{array}{l}\text { High-resolution continuum-source atomic absorp- } \\
\text { tion spectrometry }\end{array}$ \\
\hline MTT & $\begin{array}{l}\text { 3-(4,5-Dimethylthiazol-2-yl)-2,5-diphenyltetrazolium } \\
\text { bromide }\end{array}$ \\
\hline NSAID & Nonsteroidal anti-inflammatory drug \\
\hline
\end{tabular}

$\begin{array}{ll}\text { PG } & \text { Prostaglandin } \\ \text { qPCR } & \text { Quantitative real time polymerase chain reaction } \\ \text { SD } & \text { Standard deviation } \\ \text { SE } & \text { Standard error } \\ \text { THF } & \text { Tetrahydrofurane. }\end{array}$

\section{Conflicts of interest}

There are no conflicts to declare.

\section{Acknowledgements}

We thank Philipp Schuster and Sina Katharina Götzfried (University of Innsbruck, Department of Pharmaceutical Chemistry) for resynthesizing the compounds and for performing the HPLC analysis, Peter Enoh (University of Innsbruck, Department of Pharmaceutical Chemistry) for carrying out the high-resolution mass spectrometry and Caroline Gallati (University of Innsbruck, Department of Pharmaceutical Chemistry) for measuring the ${ }^{1} \mathrm{H}-\mathrm{NMR}$ spectra.

\section{References}

1 D. L. Simmons, R. M. Botting and T. Hla, Pharmacol. Rev., 2004, 56, 387-437.

2 A. L. Blobaum and L. J. Marnett, J. Med. Chem., 2007, 50, 1425-1441.

3 K. Kawaguchi, R. W. Hickey, M. E. Rose, L. Zhu, J. Chen and S. H. Graham, Brain Res., 2005, 1050, 130-137.

4 T. Yang, Acta Physiol. Scand., 2003, 177, 417-421.

5 M. Murakami and I. Kudo, Prog. Lipid Res., 2004, 43, 3-35.

6 M. N. A. Khan and Y. S. Lee, Med. Res. Rev., 2011, 31, 161201.

7 M. Regulski, K. Regulska, W. Prukała, H. Piotrowska, B. Stanisz and M. Murias, Drug Discovery Today, 2016, 21, 598-615.

8 F. J. Giles, H. M. Kantarjian, B. N. Bekele, J. E. Cortes, S. Faderl, D. A. Thomas, T. Manshouri, A. Rogers, M. J. Keating, M. Talpaz, S. O'Brien and M. Albitar, Br. J. Haematol., 2002, 119, 38-45.

9 S. Gupta, M. Srivastava, N. Ahmad, D. G. Bostwick and H. Mukhtar, Prostate, 2000, 42, 73-78.

10 K. Uefuji, T. Ichikura and H. Mochizuki, Clin. Cancer Res., 2000, 6, 135-138.

11 F. L. Queiroga, I. Pires, M. Parente, H. Gregório and C. S. Lopes, Vet. J., 2011, 189, 77-82.

12 H. Sheng, J. Shao, J. D. Morrow, R. D. Beauchamp and R. N. DuBois, Cancer Res., 1998, 58, 362-366.

13 D. F. Legler, M. Bruckner, E. Uetz-von Allmen and P. Krause, Int. J. Biochem. Cell Biol., 2010, 42, 198-201.

14 M. Nakanishi and D. W. Rosenberg, Semin. Immunopathol., 2013, 35, 123-137. 
15 T. M. Brasky, M. R. Bonner, K. B. Moysich, H. M. OchsBalcom, C. Marian, C. B. Ambrosone, J. Nie, M. H. Tao, S. B. Edge, M. Trevisan, P. G. Shields and J. L. Freudenheim, Breast Cancer Res. Treat., 2011, 126, 157-165.

16 F. M. Robertson, M. Bondy, W. Yang, H. Yamauchi, S. Wiggins, S. Kamrudin, S. Krishnamurthy, H. Le-Petross, L. Bidaut, A. N. Player, S. H. Barsky, W. A. Woodward, T. Buchholz, A. Lucci, N. Uenoand and M. Cristofanilli, CA-Cancer J. Clin., 2010, 60, 351-375.

17 K. Ng, J. A. Meyerhardt, A. T. Chan, K. Sato, J. A. Chan, D. Niedzwiecki, L. B. Saltz, R. J. Mayer, A. B. Benson, P. L. Schaefer, R. Whittom, A. Hantel, R. M. Goldberg, A. P. Venook, S. Ogino, E. L. Giovannucci and C. S. Fuchs, J. Natl. Cancer Inst., 2015, 107, dju345.

18 P. Li, H. Wu, H. Zhang, Y. Shi, J. Xu, Y. Ye, D. Xia, J. Yang, J. Cai and Y. Wu, Gut, 2015, 64, 1419-1425.

19 K. Schmidt, M. Jung, R. Keilitz, B. Schnurr and R. Gust, Inorg. Chim. Acta, 2000, 306, 6-16.

20 I. Ott, B. Kircher, C. P. Bagowski, D. H. W. Vlecken, E. B. Ott, J. Will, K. Bensdorf, W. S. Sheldrick and R. Gust, Angew. Chem., Int. Ed., 2009, 48, 1160-1163.
21 B. Hinz and K. Brune, J. Pharmacol. Exp. Ther., 2002, 300, 367-375.

22 C. A. Rouzer and L. J. Marnett, J. Lipid Res., 2009, 50, S29S34.

23 N. Chandrasekharan and D. L. Simmons, Genome Biol., 2004, 5, 241.

24 L. J. Marnett and A. S. Kalgutkar, Trends Pharmacol. Sci., 1999, 20, 465-469.

25 K. Umezu, F. Tabuchi and Y. Kimura, J. Fluorine Chem., 2003, 121, 97-99.

26 B. Neises and W. Steglich, Angew. Chem., 1978, 90, 556-557.

27 I. Ott, K. Schmidt, B. Kircher, P. Schumacher, T. Wiglenda and R. Gust, J. Med. Chem., 2005, 48, 622-629.

28 V. Obermoser, M. E. Urban, M. S. Murgueitio, G. Wolber, U. Kintscher and R. Gust, Eur. J. Med. Chem., 2016, 124, 138-152.

29 R. Gust, B. Schnurr, R. Krauser, G. Bernhardt, M. Koch, B. Schmid, E. Hummel and H. Schönenberger, J. Cancer Res. Clin. Oncol., 1998, 124, 585-597.

30 I. Ott, H. Scheffler and R. Gust, ChemMedChem, 2007, 2, 702-707.

31 M. M. Bradford, Anal. Biochem., 1976, 72, 248-254. 